\title{
Candida albicans exocellular antigens released into a synthetic culture medium: characterization and serological response in rabbits
}

\author{
Juan M. Aguiar, ${ }^{1 *}$ Fernando Baquero ${ }^{1}$ and JefFrey M. Jones ${ }^{2.3}$ \\ ${ }^{1}$ Department of Microbiology, Ramón y Cajal Hospital, Madrid, Spain 28034 \\ ${ }^{2}$ Research Service, William S. Middleton Veterans Hospital, Madison, Wisconsin 53705, USA \\ ${ }^{3}$ Infectious Diseases Section, Department of Medicine, University of Wisconsin Medical School, Madison, \\ Wisconsin 53792, USA
}

(Received 11 January 1993; revised 18 May 1993; accepted 2 July 1993)

\begin{abstract}
Different exocellular extracts were isolated by concentrating the supernatants of yeast- and mycelial-phase Candida albicans cultures incubated in a synthetic medium. The only difference between the extracts obtained from the two phases was the presence in those obtained from mycelial cultures of a polysaccharide-rich, high-molecularmass component, migrating in SDS-polyacrylamide gels at a position that would correspond to proteins with molecular masses of 245-265 kDa. The electrophoretic band patterns obtained before and after concanavalin ASepharose $4 \mathrm{~B}$ affinity column treatments confirmed that the $245-265 \mathrm{kDa}$ band was the only one of mannoprotein nature. The extract obtained from $24 \mathrm{~h}$ mycelial-phase culture (EA) was selected as the exocellular antigen for this work. The dry weight of EA obtained from 1 litre of culture medium was $30 \mathrm{mg}$; it contained $53 \%$ carbohydrate (18.3\% glucose and $21.7 \%$ mannose measured by gas-liquid chromatography) and $10 \%$ protein. Rabbit antisera against EA were absorbed with yeast-phase organisms and used to stain Western blots of gels loaded with EAs. These antisera clearly recognized bands in the 21,33 and $44 \mathrm{kDa}$ areas. The antiserum obtained was employed to develop a double-antibody enzyme-linked immunosorbent assay for measuring EA concentrations in a culture medium. Most of the EA was released during the exponential phase of growth.
\end{abstract}

\section{Introduction}

The opportunistic pathogen Candida albicans is a serious agent of infection in immunocompromised patients (Odds, 1988). C. albicans grows either by budding, leading to the formation of blastoconidia, or by production of germ tubes, giving rise to continuous septate hyphae. The yeast phase of $C$. albicans usually colonizes skin folds, mucous membranes and the intestinal ducts; however, both morphologies are found simultaneously in infected tissues (Scherwitz, 1982). The formation of germ tubes is thought to be important in the adherence of fungal cells to host epithelium (Lee \& King, 1983; Sobel et al., 1984) and in the avoidance of ingestion by phagocytic cells (Smith, 1985).

More information about the precise identity of cell components released into the surrounding medium is needed. Cell wall mannans and cytoplasmic antigens

\footnotetext{
*Author for correspondence. Tel. +3413166053 ; fax +341336 9016.

Abbreviations: Con A, concanavalin A; EA, (mycelial) exocellular antigen; PAS, periodic acid/Schiff method; WB, Western blot(ting).
}

have been demonstrated, in high concentrations, in sera of patients with severe candidiasis (Bailey et al., 1985; Meckstroth et al., 1981). These cell components are probably released into infected tissues and could participate in triggering local inflammatory responses. However, at the present time it remains unknown whether cell wall antigens, other than mannans or defined cytoplasmic antigens, are released into infected tissues. As a first step towards identifying these antigens, we believe that compounds released by $C$. albicans in culture media should be investigated. Several groups have shown the presence of extracellular material in culture filtrates from yeast-phase organisms, grown on complex media, and incubated for $7 \mathrm{~d}$ or more (Louria et al., 1963; Mankowski, 1968; Masler et al., 1966; Sikl et al., 1964). Torosantucci et al. (1991) have studied the molecular composition and antigenicity of the concanavalin A (Con A)-reactive mannoproteins released from $C$. albicans, but there is very little information about the proteins and polysaccharide components released into culture media.

As the diagnosis of invasive candidiasis remains problematic, some of the components released by 
invasive mycelial-phase Candida cells may serve as antigens in serodiagnostic tests. It is expected that these tests would be more indicative of deep infection than those currently used, which are based on yeast-phase organisms.

The purposes of this investigation were: (i) to characterize the exocellular antigens obtained from concentrated filtrates of mycelial- and yeast-phase cultures grown on synthetic medium; (ii) to characterize the antibody response to exocellular antigens, obtained from $24 \mathrm{~h}$ mycelial cultures (EA), in rabbits using enzymelinked immunosorbent assay (ELISA) and Western blotting (WB); and (iii) to investigate the kinetics of EA release into culture medium using a solid-phase doubleantibody ELISA. The ultimate goal is to develop reliable serodiagnostic assays for detecting both well-defined Candida antigens, and the antibodies against these same antigens, in patients at high risk of serious candidal disease.

\section{Methods}

Organisms and culture media. C. albicans strains were grown on Sabouraud agar slants at $25^{\circ} \mathrm{C}$ for $48 \mathrm{~h}$. Unless otherwise specified, a strain from the American Type Culture Collection, ATCC 14053, was used in all work reported here. For some experiments strains IP 3153A (Institut Pasteur Collection) and RYC 17321-87 (Ramón y Cajal Hospital Collection) were used. The cells were washed twice with sterile distilled water and $10^{7}$ blastoconidia were inoculated into $250 \mathrm{ml}$ of minimal medium supplemented with amino acids (Lee et al., 1975). After $18 \mathrm{~h}$ at $25^{\circ} \mathrm{C}$ on a gyratory shaker $(125$ r.p.m.), the cells were harvested and inoculated at a concentration of $10^{6}$ blastoconidia $\mathrm{ml}^{-1}$, into an Erlenmeyer flask containing 1 litre of the same medium. It was incubated at $25^{\circ} \mathrm{C}$ for $24 \mathrm{~h}$ under agitation (125 r.p.m.). To obtain mycelial-phase growth, another Erlenmeyer flask, containing 1 litre of the same medium prewarmed to $37^{\circ} \mathrm{C}$, was inoculated following the same protocol and incubated at $37^{\circ} \mathrm{C}$ for $24 \mathrm{~h}$. Cells grown under these conditions were $90 \%$ mycelial and $10 \%$ yeast cells.

Exocellular antigen preparation. To concentrate culture filtrates, the cells were removed by centrifugation at $2000 \mathrm{~g}$ for $5 \mathrm{~min}$. The supernatants were passed through $0.45 \mu \mathrm{m}$ pore-size membrane filters to ensure the removal of any remaining cells. Sodium azide and phenylmethylsulphonyl fluoride were added at concentrations of $0.01 \%$ $(\mathrm{w} / \mathrm{v})$ and $1 \mathrm{~mm}$, respectively. The culture filtrates were then concentrated by ultrafiltration with YM5 Diaflo membranes (Amicon) to a final volume of $30 \mathrm{ml}$. The concentrates were filtered as above, dialysed against deionized water at $4{ }^{\circ} \mathrm{C}$ for $48 \mathrm{~h}$, and lyophilized. When the extract obtained from the concentration of $24 \mathrm{~h}$ mycelial-phase cultures of strain ATCC 14053 had been chosen as the most suitable EA to study, the same extract was obtained from strains IP 3153A and RYC 17321-87.

Kinetics of EA release into the culture medium. Seven Erlenmeyer flasks, containing $50 \mathrm{ml}$ medium prewarmed to $37^{\circ} \mathrm{C}$, were inoculated following the same protocol. They were incubated at $37^{\circ} \mathrm{C}$ for $1,2,4$, $8,24,48$ and 72 h, with shaking ( 125 r.p.m.). The $\mathrm{OD}_{660}$ of each culture was measured using a Bausch and Lomb spectrophotometer. Once the cells had been removed by centrifugation and the supernatants filtered as described above, the EA concentrations of each culture were measured using the double-antibody sandwich ELISA described below.
Analysis of the EA. For quantitative analysis, measurements of protein concentration were performed with the BCA-protein assay (Pierce) according to the manufacturer's directions, using bovine serum albumin (BSA) as the standard.

Neutral sugars were measured by the anthrone procedure with glucose as the standard (Loewus, 1952). The polysaccharides from EAs were hydrolysed with $2 \mathrm{M}-\mathrm{H}_{2} \mathrm{SO}_{4}$ at $100{ }^{\circ} \mathrm{C}$ for $4 \mathrm{~h}$ and neutralized with barium carbonate. The neutral sugars, converted into the corresponding alditol acetates, were identified and quantified by gas-liquid chromatography (GLC) on a column of $3 \%$ SP-2340 on $100-120$ Supelcoport. A $2 \mathrm{~m} \times 2 \mathrm{~mm}$ glass column was used at $200-230^{\circ} \mathrm{C}$, with a temperature rise of $10^{\circ} \mathrm{C} \mathrm{min}^{-1}$, a $3 \mathrm{~min}$ initial hold, and a final temperature time of $10 \mathrm{~min}$. The $\mathrm{N}_{2}$ flow rate was $30 \mathrm{ml} \mathrm{min}^{-1}$. A flame ionization detector was used in a Perkin-Elmer 10 and Sigma 3 chromatograph. Peaks were identified on the basis of sample coincidence with the relative retention times of the standard. Inositol was used as the internal standard.

IR spectra were obtained by the $\mathrm{KBr}$ technique on a Perkin-Elmer 457 IR spectrophotometer,

$S D S-P A G E$. Fractions of the extracts containing $30 \mathrm{mg} \mathrm{ml}^{-1}$ were solubilized in sample buffer $[0.01 \mathrm{M}$-Tris $/ \mathrm{HCl}(\mathrm{pH} 6 \cdot 8), 2 \%(\mathrm{w} / \mathrm{v})$ SDS, $2 \%(\mathrm{v} / \mathrm{v})$ mercaptoethanol, $20 \%(\mathrm{v} / \mathrm{v})$ glycerol, $0.2 \%(\mathrm{w} / \mathrm{v})$ bromophenol blue]. Ten microlitres of each sample was placed on a 6,9 or $12 \%(\mathrm{w} / \mathrm{v})$ SDS-PAGE minigel and electrophoresed as described by Laemmli (1970), using the Mini-Protean II system (Bio-Rad). The molecular masses were calculated by comparing the electrophoretic mobilities of the bands with the mobilities of the molecular mass marker proteins (Dalton Mark VI and VII, Sigma). Some of the gels were stained for proteins by the Coomassie blue and silver nitrate methods, or for carbohydrates by the periodic acid/Schiff (PAS) method (Kapitany \& Zebrowsky, 1973).

Con A affinity chromatography. The EA was passed through Con ASepharose 4B (Pharmacia Fine Chemicals) affinity columns to remove the mannan and glucan, and also the mannan-protein and glucanprotein complexes. The loading and running buffer was $0.05 \mathrm{M}-$ Tris/ $\mathrm{HCl}\left(\mathrm{pH} \mathrm{7.4)}, 0.02 \%\right.$ (w/v) $\mathrm{NaN}_{3}, 0.001 \mathrm{~m}-\mathrm{MnCl}_{2}, 0.001 \mathrm{M}-$ $\mathrm{MgCl}_{2}, 0.001 \mathrm{M}-\mathrm{CaCl}_{2}$. The unbound fraction was pooled, dialysed and lyophilized.

ELISA for anti-EA antibodies. An indirect ELISA was used for the detection and quantification of anti-EA antibodies. The optimal concentrations of antigens, sera and second antibodies were predetermined by checkerboard titrations. These were carried out with known positive sera that reacted positively in the Ouchterlony immunodiffusion test at a titre of $1: 8$, as well as with negative sera to determine an optimal positive:negative ratio. Wells of polystyrene microtitre plates were coated with $100 \mu \mathrm{lEA}\left[5 \mathrm{ng} \mathrm{m}^{-1}\right.$ in phosphate-buffered saline (PBS: $120 \mathrm{~mm}-\mathrm{NaCl}, 2.7 \mathrm{~mm}-\mathrm{KCl}, 10 \mathrm{~mm}$-phosphate buffer salts)] by passive absorption overnight at $4{ }^{\circ} \mathrm{C}$. Coated plates were washed with PBS containing $0.05 \%$ Tween 20 (PBST). Serial dilutions of the sera, ranging from $1 / 40$ to $1 / 5120$, in PBST containing $5 \mathrm{mg} \mathrm{BSA} \mathrm{ml}^{-1}$ (PBST-BSA), were then made in the wells. Plates were incubated for $30 \mathrm{~min}$ at room temperature and washed again with PBST. Peroxidase-labelled anti-rabbit IgG (Sigma) diluted 1/3000 in PBST-BSA was added to each well and the plates were incubated at room temperature for $30 \mathrm{~min}$. After washing with PBST, $100 \mu \mathrm{l}$ freshly prepared substrate $\left(3 \mathrm{~mm}-\mathrm{H}_{2} \mathrm{O}_{2}, 10 \mathrm{~mm}-o\right.$-phenylenediamine in $0.1 \mathrm{M}$ citrate buffer, $\mathrm{pH} 5.5$ ) was added and incubated at room temperature until the colour had developed (usually less than $20 \mathrm{~min}$ ). The reaction was stopped by the addition of $100 \mu \mathrm{l} 0.5 \mathrm{M}-\mathrm{H}_{2} \mathrm{SO}_{4}$ and the colour was read at $492 \mathrm{~nm}$ on an eight-channel spectrophotometer (Titertek, Multiscan, Flow Laboratories). Preimmune rabbit sera served as the negative control. Results were expressed as ELISA titres, using the mean absorption value of the negative control plus twice the standard deviation as the threshold value. 
Anti-EA antibody production. New Zealand White rabbits were immunized with EA according to the method of Vaitukaitis (1981). Briefly, samples ( $1 \mathrm{mg}$ ) of EA were suspended in $1 \mathrm{ml}$ sterile PBS, emulsified with an equal volume of complete Freunds adjuvant. This volume was injected in 50 sequential $0.04 \mu$ subcutaneous injections, into the backs of adult rabbits.

After 6 weeks of injections, the rabbits were tested weekly for antibody responses with the ELISA test. When the anti-EA antibody titre was $\geqslant 1 / 5120$, blood was collected. Purified IgG was prepared by chromatography on DEAE-cellulose (Whatman), adjusted to $1 \mathrm{mg} \mathrm{ml}^{-1}$ with PBS, and stored at $-70^{\circ} \mathrm{C}$ until used as a coating antibody or horseradish-peroxidase-conjugated antibody in the ELISA sandwich procedure.

Peroxidase-labelled anti-EA preparation. Anti-EA antibody was conjugated to horseradish peroxidase type VI by the method of Nakene \& Kawoi (1974). Fluorodinitrobenzene-blocked peroxidase was oxidized with sodium periodate to form aldehyde groups. Peroxidasealdehyde was unidirectionally bound to free amino groups of $\operatorname{IgG}$ with a high affinity. This peroxidase-labelled immunoglobulin retained both its enzymic and immunological properties. In order to avoid nonspecific interactions between the coating antibody and the peroxidaselabelled antibody, the IgG fraction from the anti-EA antibody was coupled to a $5 \mathrm{ml}, \mathrm{CNBr}$-activated Sepharose $4 \mathrm{~B}$ column (Pharmacia), containing $1 \mathrm{mg}$ (dry wt) $\mathrm{CNBr}$. Then, $2.5 \mathrm{ml}$ peroxidase-labelled antibody was run down this column. These eluates were employed as conjugates in the ELISA sandwich procedure. Working dilutions of unlabelled coating antibody and peroxidase-labelled IgG antibody were determined by checkerboard titrations in microtitre plates with known EA dilutions in PBST-BSA and with PBST-BSA alone.

ELISA for detection of EA. For the kinetic studies, a doubleantibody sandwich ELISA for the detection of EA in culture medium was used. To each well of polystyrene microtitre plates, $100 \mu \mathrm{l}$ anti-EA antibody (containing $2.5 \mu \mathrm{g} \mathrm{IgG} \mathrm{in} \mathrm{PBS)} \mathrm{was} \mathrm{added} \mathrm{and} \mathrm{the} \mathrm{plates} \mathrm{were}$ incubated overnight at $4^{\circ} \mathrm{C}$. Prior to use, the plates were washed with PBST and blocked with $100 \mu \mathrm{l} 5 \mathrm{mg} \mathrm{BSA} \mathrm{m}^{-1}$ in PBS at room temperature for $30 \mathrm{~min}$. The plates were then washed again with PBST, $100 \mu \mathrm{l}$ culture medium (diluted 1/20 in PBST-BSA) was added to each well, and the plates incubated at room temperature for $18 \mathrm{~h}$. PBST washes were repeated. Peroxidase-labelled IgG was then added to each well ( $5 \mu \mathrm{g}$ IgG in $100 \mu \mathrm{l} \mathrm{PBST-BSA}$ ) and incubated for $3 \mathrm{~h}$ at room temperature. After washing with PBST, the ELISA was developed as described above. To obtain a standard curve, serial dilutions of EA were included, with PBS as the negative control. A representative cumulative curve was generated each time the ELISA was performed. The concentrations of EA in culture medium were extrapolated from the standard curve.

$W B$ procedure. Fractions of $50 \mu \mathrm{IEA}$ solubilized in sample buffer $\left(30 \mathrm{mg} \mathrm{ml}^{-1}\right)$ were applied to a single large well $(6.5 \mathrm{~cm})$ and separated in a $12 \%$ SDS-PAGE gel. The separated EA components were transferred onto an Immobilon PVDF transfer membrane (Millipore) in a transblot cell (Bio-Rad) at $100 \mathrm{~V}$ for $3 \mathrm{~h}$. After transfer, the region on the membrane that corresponded to the single large well was cut into 24 identical strips $\left(2.5 \mathrm{~mm}\right.$ in width) that were stored at $-20{ }^{\circ} \mathrm{C}$ and which gave identical performances over 6 months. Free protein sites were saturated by incubation at $40{ }^{\circ} \mathrm{C}$ for $1 \mathrm{~h}$ with $8.8 \%(\mathrm{v} / \mathrm{v})$ low-fat milk in Tris-buffered saline $(\mathrm{pH} 7 \cdot 4)$. The strips were then incubated at $22{ }^{\circ} \mathrm{C}$ for $1.5 \mathrm{~h}$ with sample serum diluted $1 / 100$ in the same buffer. In most cases, the sample sera were previously absorbed by mixing 15 vols heat-killed yeast-phase organisms $\left(10^{10}\right.$ cells $\left.\mathrm{ml}^{-1}\right)$ with 1 vol. serum. After incubation, with agitation, at room temperature for $2 \mathrm{~h}$, the organisms were removed by centrifugation and the absorbed sera used for WB. After washing five times in $0.9 \%(\mathrm{w} / \mathrm{v}) \mathrm{NaCl}$ and $0.05 \%(\mathrm{w} / \mathrm{v})$ Tween 20 for $30 \mathrm{~min}$, the strips were incubated at $22{ }^{\circ} \mathrm{C}$ for $1 \mathrm{~h}$ with alkaline phosphatase-goat anti-rabbit IgG, diluted 1/3000 (Bio-Rad). After another wash, the strips were incubated at $22{ }^{\circ} \mathrm{C}$ for $15 \mathrm{~min}$ in a freshly made mixture of $p$-nitro blue tetrazolium chloride and 5-bromo4-chloro-3-indolyl phosphate $p$-toluidine salt, according to the manufacturer's directions (Bio-Rad).

\section{Results}

Characterization of filtrate concentrates obtained from mycelial- and yeast-phase cultures

The array of molecular species obtained after the concentration of culture filtrates of both phases was compared by SDS-PAGE ( $12 \%$ gel). When the gels were stained with Coomassie blue, only two bands, of 33 and $44 \mathrm{kDa}$, were visible. When stained by the silver technique, the gel prepared from both phases showed a larger diversity of bands, corresponding to medium to low molecular-mass species, from $75 \mathrm{kDa}$ down to about $21 \mathrm{kDa}$ (Fig. 1). Extracts obtained from mycelial cultures contained, in addition to these common bands, another band with a high molecular mass $(245-265 \mathrm{kDa}$, see below) which did not penetrate the $12 \%$ SDS-PAGE gels and barely penetrated the $9 \%$ gels. To study the highmolecular-mass component in more detail, $6 \%$ gels were used, and the gels were stained for carbohydrates by the PAS method. All extracts produced an intense diffuse PAS stain on the upper portion of the gels. This diffusely

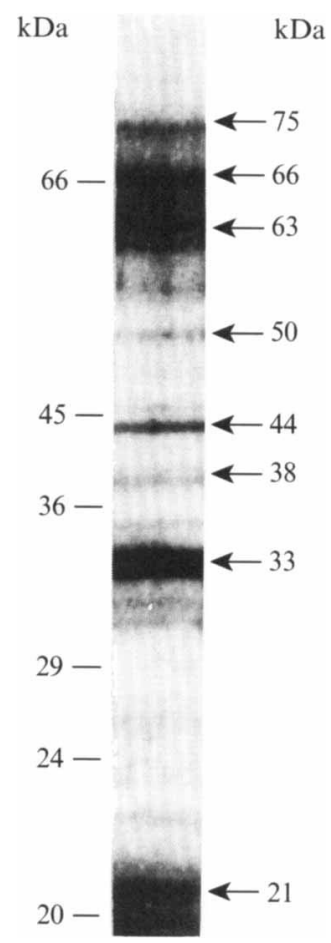

Fig. 1. SDS-PAGE ( $12 \%$ gel) of concentrates of $24 \mathrm{~h}$ mycelial culture filtrates. The gel was stained by the silver technique. Molecular mass standards are on the left; molecular masses of major bands are indicated on the right. 


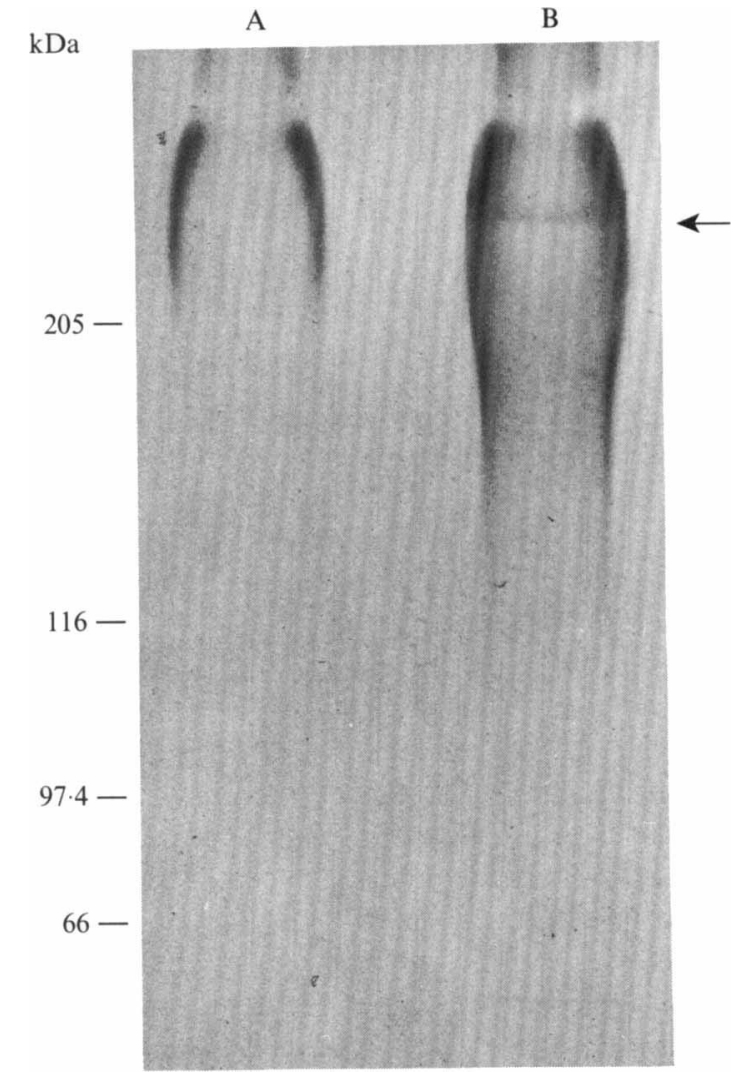

Fig. 2. SDS-PAGE ( $6 \%$ gel) of concentrates of $24 \mathrm{~h}$ yeast (lane A) and mycelial (lane B) culture filtrates. The gel was stained by the PAS technique. Molecular mass standards are on the left. The arrow points to the band detected exclusively in the mycelial culture filtrates.

stained area, in the extracts obtained from mycelial phase cultures, contained the $245-265 \mathrm{kDa}$ band which was clearly visible in $6 \%$ SDS-PAGE gels (Fig. 2). The remaining bands identified in silver-stained gels did not have a sufficient number of attached carbohydrate moieties to be detectable with the PAS stain.

EAs were obtained from the other two strains studied to prove that they were produced in $C$. albicans strains other than ATCC 14053. We analysed them, along with extracts of strain ATCC 14053, by SDS-PAGE (10\% gels). These were stained by the silver nitrate and PAS methods. The three strains showed the same array of molecular species, including the high-molecular-mass component.

\section{Yield of EAs}

The correlation between EA concentrations, $\mathrm{OD}_{660}$ and time of incubation obtained in the kinetics studies showed (in three independent assays) that most of the EA is released during the exponential phase of growth. The dry weight of EA obtained from 1 litre culture medium was $30 \mathrm{mg}$.

\section{Chemical analysis of EAs}

The extracts contained $53 \%$ carbohydrates and $10 \%$ protein by weight. Neutral sugars were released from the EA by hydrolysis with $2 \mathrm{M}-\mathrm{H}_{2} \mathrm{SO}_{4}$ for $4 \mathrm{~h}$ and, as determined by GLC, were exclusively glucose and mannose. The proportion of the two monosaccharides in the EA was $18.3 \%$ and $21.7 \%$, respectively. The IR spectra showed bands at $805 \mathrm{~cm}^{-1}$ that could be attributed to mannose residues, at $890 \mathrm{~cm}^{-1}$ that were characteristic of $\beta$-linked polysaccharides, and at 1550 $1535 \mathrm{~cm}^{-1}$ that are believed to be related to the presence of proteins (Mitchell \& Scurfield, 1970). To investigate the presence of mannoproteins, the EA was passed through Con A-Sepharose 4B affinity columns. EA and the mannan-depleted fractions were loaded in 6 and $12 \%$ SDS-PAGE gels and stained by the silver technique. The electrophoretic band patterns obtained before and after Con A treatment were the same, with the exception of the disappearance of the $245-265 \mathrm{kDa}$ band in the mannan-depleted fractions, confirming that this band was the only one of mannoprotein nature.

\section{$W B$ analysis of the serological response to $E A$ in immunized rabbits}

In order to investigate the serological response to EA in rabbits and then to determine the EA components that could be recognized in the double-antibody sandwich ELISA, blots of gels containing EA fractions were stained with rabbit anti-EA serum. The blots were completely covered by a dense staining. ManningZweerink et al. (1986) described a similar result using yeast cell extracts of $C$. albicans as the antigen. This diffuse stain is probably due to the presence in EA of mannoproteins from the cell surface. To overcome this, the rabbit antiserum was absorbed with yeast cells, which resulted in a clear reduction in this dense and diffuse staining. However, in most cases the upper portion of each blot remained stained (Fig. 3), suggesting the presence of a heterogeneous antigen, possibly polysaccharide and/or glycoproteins. As the absorption process removes the anti-yeast-surface-antigen antibodies, the rabbit antiserum may be recognizing different components from those present on the yeast surface. The antiserum also clearly recognized bands in the 21,33 and $44 \mathrm{kDa}$ areas. In the $33 \mathrm{kDa}$ area, the antiserum recognized two bands, indicating that the $33 \mathrm{kDa}$ antigen may be composed of two proteins with very similar molecular masses. Bands in the $26-28$ and $50 \mathrm{kDa}$ areas were also recognized but had a lower intensity. It was impossible to estimate the serological response to the 63, 66 and $75 \mathrm{kDa}$ bands as the diffuse staining covered the area in which these bands were situated. 


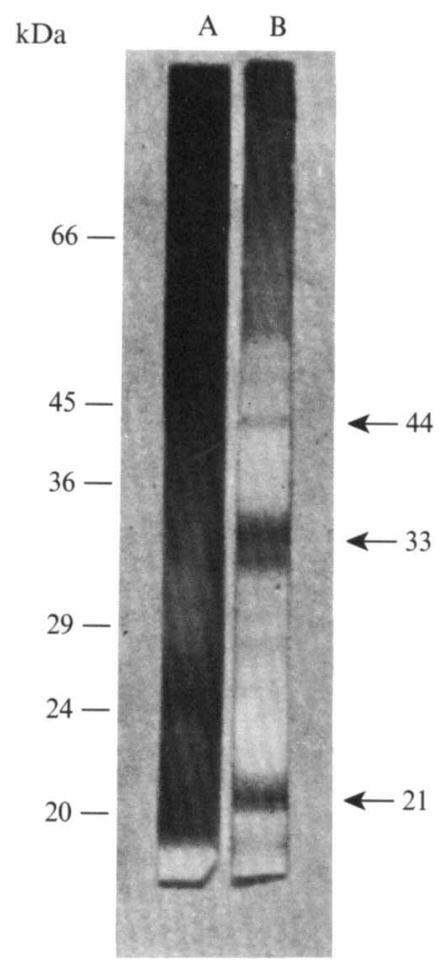

Fig. 3. WB analysis of $C$. albicans exocellular antigens (separated in $12 \%$ SDS-PAGE) reacted against rabbit antiserum $(1: 100)$ to the same antigen (lane A) and against the antiserum absorbed with yeast cells (lane B). The molecular masses of major bands are indicated on the right; molecular mass standards are on the left.

\section{Discussion}

In the studies reported here, we attempted to demonstrate the array of protein, glycoprotein and polysaccharide components released into a synthetic culture medium by $C$. albicans. The identification of these components could provide the basis for a better understanding of virulence factors, including those involved in local inflammatory reactions, or for the development of new antigens to be used in the serodiagnosis of Candida infections. One of the first ways in which such diagnostic antigens were obtained was by the concentration of culture filtrates. During the nineteen sixties, yeast-phase cultures, incubated for up to 4 weeks, were widely used to obtain antigens (Louria et al., 1963; Mankowski, 1968; Masler et al., 1966; Sikl et al., 1964). These antigens showed cross-reactivity with antigenic preparations from the cell wall and the cytoplasm, and may therefore be considered as autolytic products rather than secreted components (Masler et al., 1966; Tsachdjian et al., 1967). The exocellular antigen preparations obtained in this work were obtained from concentrates, not only of yeast, but also from mycelial-phase cultures on synthetic medium incubated for $24 \mathrm{~h}$. Torosantucci et al. (1991) also studied the material released by yeast- and mycelial-phase $C$. albicans into a chemically defined, simple medium after $24 \mathrm{~h}$ growth; however they only characterized the Con-A-reactive mannoprotein constituents. They demonstrated that both phases release comparable amounts of such mannoproteins. The polydisperse electrophoretic pattern of their mannoproteins makes it difficult to compare with the pattern described by us; in particular, they do not provide sufficient data about the high molecular mass components ( $>200 \mathrm{kDa}$ ). Torosantucci et al. (1991) did not find qualitative differences between the two extracts. We were able to demonstrate, by the use of a different medium composition and concentration procedure, the presence, in the extracts obtained from mycelial cultures, of a band with high molecular mass $(245-265 \mathrm{kDa})$. Previous studies have indicated that there are antigens which are expressed preferentially in germ tube cell walls of $C$. albicans (Ponton \& Jones, 1986; Smail \& Jones, 1984; Sundstrom \& Kenny, 1984, 1985), and which can also be extracted from mycelial-phase organisms by various techniques. The fact that specific mannoproteins are expressed during germ tube formation suggests that changes in cell surface molecules may be related to differences in wall architecture and properties. Casanova et al. (1989) have demonstrated the presence of a $260 \mathrm{kDa}$ glycoprotein specific to the mycelial cell wall. They also showed that this component is synthesized and incorporated into the cell wall structure concomitantly with germ tube formation, the mannoprotein composition of the blastoconidia cell wall being unaltered. The mannoprotein described in our work has been detected exclusively in supernatants from mycelial-phase cultures and, as we have shown in kinetic studies, most of the EA is released during the first hours of growth, during the transition from blastoconidia to germ tubes. Owing to similarities in molecular mass and composition, we consider it very likely that the $260 \mathrm{kDa}$ component, exclusive to mycelial cells, is also released into the culture medium during germ tube formation. As the transition from blastoconidia to germ tubes occurs mainly during tissue invasion, the detection of this glycoprotein, or specific antibodies against it, may be a very specific indicator of severe candidiasis. Unfortunately, it was impossible to determine the serological response to this mannoprotein produced in rabbits because, once absorbed with yeast cells, the rabbit antiserum still recognized a heterogeneous polysaccharide or glucoprotein antigen in the EA, that was probably not exposed on the surface of the cell.

In the preparation of our exocellular antigens we used shorter incubation times (less than $3 \mathrm{~d}$ ) so as to prevent potential contamination with non-specific autolytic products appearing late in cultures. McCourtie \& Douglas (1985) also used supernatants from cultures incubated for less than $3 \mathrm{~d}$. They isolated extracellular material 
from culture supernatants of $C$. albicans, grown on different carbon sources, by acetone precipitation. This material contained mainly carbohydrates (65-82\%; mannose with some glucose) and protein ( $7 \%$ ). Unfortunately, data on the molecular mass of these components was not reported by the authors. The extract obtained by us, however, contained almost equal amounts of glucose and mannose. Elorza et al. (1983) have reported that the amount of mannan is at least five times less in the yeast phase than in the mycelial phase. This could account for the smaller amount of mannans detected by us in the supernatants from mycelial-phase cultures.

We used a synthetic medium to obtain mycelial-phase exocellular antigens. Some complex media are inducers of exocellular proteins which have been used as antigens for serodiagnosis, but equivocal results were obtained, at least for proteinase (Macdonald \& Odds, 1980). The use of the exocellular mycelial antigen obtained in this work in more specific serological tests for patients at high risk of severe candidiasis is being tested at present in our laboratory.

We thank Teresa Montero, Luisa M. Villar, Jose Pontón and Juan A. Leal for helpful discussions.

This work was supported by a grant from the 'Fondo de Investigaciones Sanitarias de la Seguridad Social', Spain.

\section{References}

Bailey, J. W., Sada, E., Brass, E. \& Bennett, J. E. (1985). Diagnosis of systemic candidiasis by latex agglutination for serum antigen. Journal of Clinical Microbiology 21, 749-752.

Casanova, M., Gil, M. L., Cardeñoso, L., Martinez, J. P. \& Sentandreu, R. (1989). Identification of wall-specific antigens synthesized during germ tube formation by Candida albicans. Infection and Immunity 57, 262-271.

Elorza, M. V., Rico, H., Gozalbo, D. \& Sentandreu, R. (1983). Cell wall composition and protoplast regeneration in Candida albicans. Antonie van Leeuwenhoek 49, 457-469.

Kapitany, R. A. \& Zebrowsky, E. J. (1973). A high resolution PAS stain for polyacrylamide gel electrophoresis. Analytical Biochemistry 56, 361-369.

LaEmmLi, U. K. (1970). Cleavage of structural proteins during the assembly of the head of bacteriophage T4. Nature, London 227, $680-685$.

LEE, J. C. \& KING, R. D. (1983). Characterization of Candida albicans adherence to human vaginal epithelial cells in vitro. Infection and Immunity 41, 1024-1030.

Lee, K. L., BuCKLey, H. R. \& CAmpbell, C. C. (1975). An amino acid liquid synthetic medium for the development of mycelial and yeast forms of Candida albicans. Sabouraudia 13, 148-153.

LoEWUS, F. A. (1952). Improvement in the anthrone method for determination of carbohydrates. Analytical Chemistry 24, 219-222.
Louria, D. B., Brayton, R. G. \& Finkel, G. (1963). Studies on the pathogenesis of experimental Candida albicans infections in mice. Sabouraudia 2, 271-283.

Macdonald, F. \& Odds, F. C. (1980). Purified Candida albicans proteinase in the serological diagnosis of systemic candidosis. Journal of the American Medical Association 243, 2409-2411.

MANKowsKi, Z. T. (1968). Production of glycoprotein by Candida albicans in a synthetic medium and its influence on the growth of newborn mice. Mycopathologia et Mycologia Applicata 36, 113-118.

Manning-Zweerink, M., Maloney, C. S., Mitchell, T. G. \& WeSTON, H. (1986). Immunoblot analyses of Candida albicansassociated antigens and antibodies in human sera. Journal of Clinical Microbiology 23, 46-52.

Masler, L., SikL, D., Bauer, S. \& Sandula, J. (1966). Extracellular polysaccharide-protein complexes produced by selected strains of Candida albicans. Folia Microbiologica 11, 373-378.

MCCourTIE, J. \& Douglas, L. J. (1985). Extracellular polymer of Candida albicans: isolation, analysis and role in adhesion. Journal of General Microbiology 131, 495-503.

Meckstroth, K. L., Reiss, E., Keller, J. W. \& Kaufman, L. (1981). Detection of antibodies and antigenemia in patients with candidiasis by enzyme-linked immunosorbent assay. Journal of Infectious Diseases 144, 24-32.

Mitchell, A. J. \& SCurfield, G. (1970). An assessment of infrared spectra as indicators of fungal cell wall composition. Australian Journal of Biological Sciences 23, 345-360.

Nakene, P. K. \& Kawor, A. (1974). Peroxidase-labelled antibody, a new method of conjugation. Journal of Histochemistry and Cytochemistry 22, 1084-1091.

ODDs, F. C. (1988). Introduction and historical note. In Candida and Candidosis, 2nd edn, pp. 1-5. Philadelphia: Bailliere Tindall.

Ponton, J. \& Jones, J. M. (1986). Identification of two germ-tubespecific cell wall antigens of Candida albicans. Infection and Immunity 54, 864-868.

SCHER WITZ, C. (1982). Ultrastructure of human cutaneous candidiasis. Journal of Investigative Dermatology 78, 200-205.

SikL, D., MASLer, L. \& BAuer, S. (1964). Mannan from the extracellular surface of Candida albicans Berkhourt. Experientia 20, 456.

Smail, E. H. \& Jones, J. M. (1984). Demonstration and solubilization of antigens expressed primarily on the surfaces of Candida albicans germ tubes. Infection and Immunity 45, 74-81.

SMITH, C. B. (1985). Candidiasis: pathogenesis, host resistance and predisposing factors. In Candidiasis, pp. 53-70. Edited by G. P. Bodey \& V. Fainstein. New York: Raven Press.

Sobel, J. D., Muller, G. \& BuCKLey, H. R. (1984). Critical role of germ tube formation in the pathogenesis of candidal vaginitis. Infection and Immunity 44, 576-580.

SundSTROM, P. M. \& KenNY, G. E. (1984). Characterization of antigens specific to the surface of germ tubes of Candida albicans by immunofluorescence. Infection and Immunity 43, 850-855.

Sundstrom, P. M. \& KennY, G. E. (1985). Enzymatic release of germtube-specific antigens from cell walls of Candida albicans. Infection and Immunity 49, 609-614.

Torosantucci, A., Gomez, M. J., Casalinuovo, I. \& Cassone, A. (1991). Biochemical and antigenic characterization of mannoprotein constituents released from yeast and mycelial forms of Candida albicans. Journal of Medical and Veterinary Mycology 29, 361-372.

Tsachdian, C. L., Kozinn, P. J., Okas, A., Caroline, L. \& Halle, A. (1967). Serodiagnosis of systemic candidiasis. Journal of Infectious Diseases 117, 180-187.

VaituKaitis, J. L. (1981). Production of antisera with small doses of immunogen: multiple intradermal injections. Methods in Enzymology 73, 46-51. 